\title{
PESCANDO NUCLEOTÍDEOS: UM NOVO JOGO EDUCATIVO PARA O ENSINO DO PROCESSO DE SÍNTESE PROTÉICA PARA ESTUDANTES DO ENSINO MÉDIO.
}

\author{
Fábio T. Moroni ${ }^{1}$ Raquel B. Moroni ${ }^{1}$, Silvia C. B. Justiniano ${ }^{2}$ \& Joselita M. M. dos \\ Santos ${ }^{3}$ \\ 1 - Instituto de Ciências Biológicas/ Universidade Federal do Amazonas (UFAM/ICB). \\ 2 - Centro Universitário Nilton Lins (CUNL). \\ 3 - Instituto Nacional de Pesquisas da Amazônia (INPA)
}

\section{Resumo:}

Um novo jogo, usando analogias, apresenta os principais aspectos da síntese protéica. 0 objetivo desta prática é melhorar a aprendizagem sobre o processo de síntese protéica para estudantes no ensino médio. Nós utilizamos materiais de baixo custo e de fácil acesso para o desenvolvimento deste jogo. Para que os alunos compreendam a teoria de é necessário uma aula introdutória sobre a síntese protéica, antes de a aplicação desta prática. Para jogar, os alunos são divididos em dois grupos. O professor fornece a cada grupo uma ficha, representando um aminoácido e uma tabela com o código genético. Os alunos começam o jogo ao responder as perguntas feitas pelo adversário para conseguir a permissão para a pesca da base nitrogenada. Se a resposta estiver correta a base nitrogenada será entregue para o grupo, que terá que preencher um painel que contém seqüências correspondentes ao RNA mensageiro, DNA complementar e DNA molde, decodificados a partir do aminoácido fornecidos pelo professor no início do jogo. O primeiro grupo que completar todas as etapas da síntese protéica ganha o jogo. A aplicação desta prática nas escolas do nível médio da cidade de Manaus obteve uma excelente aceitação pelos profissionais da educação, que relataram o grande entusiasmo dos seus alunos para utilizar o jogo e uma melhora na compreensão do tema abordado em sala de aula. Os professores também comentaram a versatilidade desta prática, que foi utilizada com sucesso para abordar outras questões. Logo o jogo é uma prática que pode ser desenvolvido para complementar as aulas teóricas sobre o assunto.

\begin{abstract}
:
A new game, using analogies, presents the main aspects of protein synthesis. The purpose of this practice is to improve learning about the process of protein synthesis for students in high school. We use low cost and easy access materials to the development of this game. For students to understand the theory must be an introductory lecture on protein synthesis, before the implementation of this practice. To play, students are divided into two groups. The teacher gives each group a plug, representing an amino acid and a table with the genetic code. Students start the game by answering the questions raised by the opponent to get the permission for fishing from the nitrogen base. If the answer is correct the nitrogen bases will be delivered to the group, which will have to fill a panel that contains sequences corresponding to the messenger RNA, DNA and complementary DNA template, decoded from the amino acid provided by the teacher early in the game. The first group to complete all the steps of protein synthesis wins the game. The application of this practice in schools in the high schools of the Manaus city returned an excellent acceptance by the teachers, who reported the great enthusiasm of his students to use the game and an improvement in the understanding of the issue addressed in the classroom. Teachers also commented on the versatility of this practice, which was successfully used to address other issues. So the game is a practice that can be developed to complement the theoretical classes on the subject.
\end{abstract}




\section{INTRODUÇÃo}

Atualmente uma forte tendência na formulação dos princípios curriculares para - Ensino Médio é a complementação das aulas expositivas com práticas que favoreçam a interdisciplinaridade e a contextualização curricular [1-5].

Ensinar o processo de síntese protéica e outros aspectos da bioquímica das biomoléculas para estudantes do ensino médio ainda tem sido um grande desafio, pois são temas importantes para a compreensão dos avanços da biotecnologia e fundamentais para discussões sobre a bioética, porem são abstratos na percepção dos estudantes [6-7].

Para minimizar essa dificuldade foi elaborado um jogo, no qual os principais aspectos da síntese de proteínas são apresentados aos estudantes utilizando o recurso das analogias. Essas são representações utilizadas para compreender uma nova informação por meio de elementos que os estudantes já possuem armazenados na memória [8]. Em contextos educacionais, as analogias educacionais são um recurso amplamente utilizado e seu valor potencial e reconhecido por diversos autores [9-10].

Alguns trabalhos demonstram que atividades lúdicas pedagógicas aumentam a capacidade de fixação de determinados conteúdos. A utilização de jogos como ferramenta pedagógica é uma ótima opção para auxiliar na exposição e/ou fixação dos diversos assuntos abordados durante as aulas. Resultados positivos quanto ao enriquecimento do aprendizado foram observados por professores que praticaram jogos com diferentes temas durante o ano letivo [ $11-12$ ]. O baixo custo de elaboração e a praticidade na construção de jogos em sala demonstram que é possível abordar temas científicos sem a necessidade de grandes investimentos financeiros pelas escolas [12].

Esta prática tem como objetivo facilitar o ensino sobre os princípios fundamentais do código genético, demonstrando por meio de um jogo a relação entre os processos de transcrição e tradução.

\section{MATERIAL E MÉTODOS}

Lista dos principais materiais:

2 palitos de churrasco (vara de pescar).

36 quadrados $\left(4 \mathrm{~cm}^{2}\right)$ de EVA (peixes).

36 fichas retangulares de cartolina (perguntas)

2 listas de perguntas devidamente numeradas sobre o tema referido.

1 lista contendo perguntas e resposta para uso exclusivo do professor (a).

1 piscina inflável infantil (lago ou rio).

2 folhas de cartolina (painéis)

2 metros de barbante comum (linha de anzol)

15 folhas de jornal (preenchimento da piscina)

5 folhas de papel celofane (preenchimento da piscina)

36 fichas de papel cartão ou cartolina (nucleotídeos).

4 fichas de papel cartão ou cartolina (aminoácidos).

2 palitos de picolé (ligação peptídica).

Clipes para papel, cola escolar, canetas coloridas, fita crepe, tesoura.

\section{1- Confecção dos materiais a serem utilizados na prática.}

1- Vara de pesca: para a produção das varas será utilizado palito de churrasco e para a confecção da linha de anzol será utilizado 1 metro de barbante, o qual terá uma das extremidades amarrada a um palito de churrasco e a outra em um clipe de papel modificado para ter a forma de um anzol.

2- Peixes: será usada para a confecção dos peixes borracha de etil vinil acetato (EVA) colorida e fita crepe para a fixação das bases nitrogenadas, com um número indicativo das questões que será feitas pelos membros dos grupos participantes. Os 
peixes podem ser construídos de acordo com as sugestões de medidas indicadas na Figura 1, delimitando uma área de $4 \mathrm{~cm}^{2}$ para fixar a base nitrogenada com fita crepe.

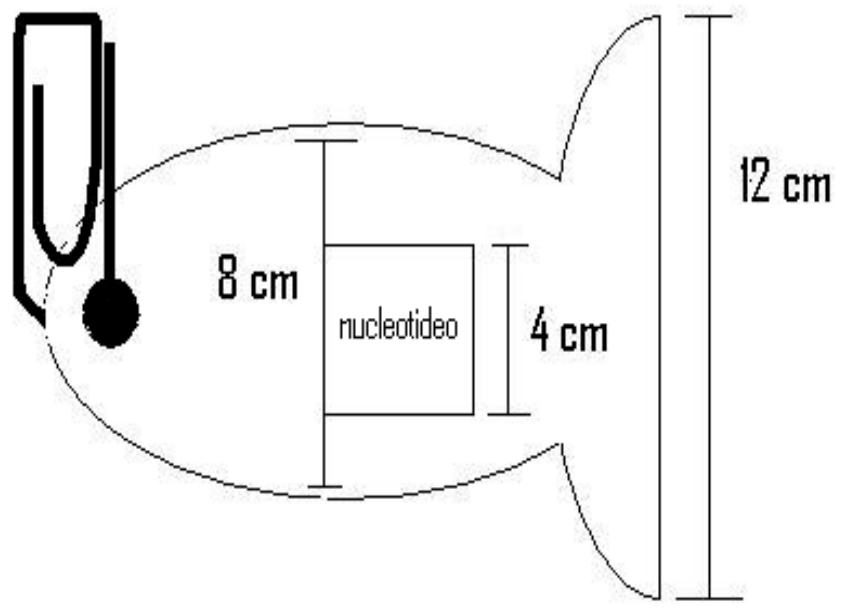

Figura 1- Molde do peixe utilizado na prática.

3- Lago ou rio: para a construção utilizada uma piscina inflável infantil ou uma caixa grande de papelão, usar folhas de jornal amassadas (para preencher a piscina) e algumas folhas de papel celofane azul, cortadas em tiras, as quais serão posicionadas acima das folhas de jornal, para simular a água. Sugestão: atribuir para a piscina nomes dos corpos de água do município, onde a prática está sendo ministrada, por exemplo: lago Janauari em Manaus (AM) ou lagoa do Broa em São Carlos (SP), criando assim um vínculo de identificação dos estudantes com a atividade.

4- Bases nitrogenadas e aminoácidos: será usada cartolina ou borracha tipo EVA, caneta colorida e tesoura. Para cada grupo serão confeccionados dezoito bases nitrogenadas e dois aminoácidos. Dois palitos para picolé serão utilizados para representar uma ligação peptídica. Após cortar a cartolina ou outro material em quadrados $\left(4 \mathrm{~cm}^{2}\right)$, as peças serão fixadas com fita crepe nos peixes confeccionados, conforme o item 2 .

5- Painéis: como sugestão os painéis podem ser produzidos na forma de uma das espécies de peixes da Amazônia.

6- Perguntas: as questões serão previamente elaboradas e numeradas, sendo utilizadas tiras de cartolina ou papel cartão com base na aula introdutória ministrada. A tabela 1 é uma sugestão com questões sobre o assunto. 
Tabela 1 - Sugestões de perguntas para o jogo Pescando nucleotídeos.

1 - Qual a base nitrogenada que pode emparelhar com as bases uracila ou timina?

2 - Qual a função da DNA polimerase?

3 - O que é duplicação do DNA?

4 - Quais foram os cientistas que estabeleceram a estrutura do RNA pela primeira vez?

5 - Quais são os compostos químicos que formam o nucleotídeo?

6 - Como é denominado um polímero composto por aminoácidos?

7 - Quais são os tipos de ácidos nucléicos?

8 - Quais os nucleotídeos que podem estar presentes na composição do DNA?

9 - Qual é a unidade estrutural e funcional dos organismos vivos?

10 - Qual a organela da célula que contém os cromossomos?

11 - Qual a molécula que contém a informação genética dos organismos vivos?

12 - Qual a molécula que leva a informação codificada no DNA para ser traduzida em proteína no citoplasma?

14 - Como é denominada a estrutura composta por DNA e encontrada no citoplasma da célula dos organismos eucariotos?

15 - Como são classificados os organismos formados por célula(s) que apresenta(m) um núcleo distinto?

16- O que são ligações peptídicas?

\subsection{Procedimento:}

O jogo deve ser aplicado após uma aula introdutória sobre processo de síntese protéica. No início do jogo devem ser formados dois grupos (1 e 2), com até 15 estudantes cada grupo. Cada grupo ganhará do professor (a) duas figuras representativas de aminoácidos, por exemplo, isoleucina e valina; um palito de picolé para representar a ligação peptídica que irá unir os aminoácidos e uma lista de questões devidamente numerada. Os grupos também receberão uma tabela de código genético, já marcada, com a trinca resultante dos referidos aminoácidos. Em seguida, o professor dará um tempo de até 5 minutos para os grupos prepararem um "rascunho" em folha A4 do painel definitivo, esquematizando as fitas de RNA mensageiro, DNA complementar e molde, a partir dos aminoácidos recebidos. Tal tempo é importante para que os grupos avaliem sobre a necessidade ou não do peixe (base nitrogenada) que foi pescado. Após a fase referida acima, o peixe (base nitrogenada) é "pescado" pelo grupo 1, sendo que um dos membros do grupo 1 informa ao grupo 2 a numeração encontrada no peixe pescado. Tal número indica a pergunta que será feita por um dos membros do grupo 2, o qual possui uma tabela de perguntas devidamente numerada, cabendo ao professor (a) averiguar a resposta do grupo da vez e indicar se está correta. Conforme o acerto da questão, o grupo 1 ganha uma peça emborrachada, que corresponde a uma base nitrogenada, a qual será destacada do peixe e fixada no painel do grupo 1, para formar as trincas correspondentes ao RNA e as fitas de DNA complementar e molde. Posteriormente o jogo segue sendo o direito de pescar mantido pelo grupo 1, devido a resposta correta da questão. Caso o grupo 1 não acerte a pergunta, ou se o nucleotídeo não servir para o grupo, o peixe pescado voltará para o rio ou lago e passa a vez para o grupo 1. Ganha o jogo o grupo que primeiro montar as fitas de RNA mensageiro, DNA complementar e DNA molde.

\section{3- RESULTADOS E DISCUSSÃO DA PRÁTICA.}

Essa prática foi aplicada em cursos educacionais, realizados desde 2003, envolvendo professores e estudantes de ensino médio de escolas privadas e públicas de Manaus-Amazonas. Vale ressaltar, que tal prática também foi demonstrada em dois eventos científicos realizados na cidade Manaus nos anos de 2005 e 2006, respectivamente, a Reunião Anual da SBPC e a Semana de Biotecnologia da Universidade Estadual do Amazonas. 
O conhecimento dessa prática pelos professores tem sido uma forma alternativa de aprendizagem, havendo relatos por parte de professores e estudantes de uma melhoria na compreensão da síntese protéica. Também foi mencionado pelos professores, que o jogo quando realizado após a aula expositiva, propiciou uma melhor assimilação de conceitos relacionados a síntese protéica, considerados difíceis de compreensão até então pelos os estudantes do ensino médio. Tal constatação foi observada também em decorrência das melhores notas obtidas pelos estudantes nas avaliações, quando comparada com os anos que não houve a aplicação do jogo.

Além disso, foi relatado pelos professores um aumento na expressão da criatividade dos estudantes, por meio de sugestões no sentido de estar estimulando os professores para o emprego dos jogos em outras disciplinas com outros temas.

\section{4- CONCLUSÃO}

Em síntese, a mudança de atitude dos professores e estudantes em relação à aplicação do jogo "Pescando nucleotídeos" foi evidente, havendo um maior interesse para a busca de formas alternativas para o melhor entendimento dos diversos temas ministrados em sala de aula.

\section{REFERÊNCIAS BIBLIOGRÁFICAS}

[1] Brito, E. A. Favaretto, J. A. (1997). Biologia: uma abordagem evolutiva e ecológica, Editora Moderna, São Paulo.

[2] Domingues, J.J., Toschi, N.S., Oliveira, J. F. (2000). A reforma do Ensino Médio: A nova formulação curricular e a realidade da escola pública, Educação \& Sociedade XXI, 70, Abril, 63-79.

[3] Frota - Pessoa, O. (2001). Os caminhos da biologia: biologia no ensino médio, Editora Scipione, São Paulo.

[4] Soares, J. L. (2001).Biologia, Editora Scipione, São Paulo.

[5] BRASIL (2006).Portaria No. 501, de 14 de fevereiro de 2006,Diário Oficial [da Republica Federativa do Brasil], Brasília, DF, n. 33, 15 fev. Seção 1, p.

[6] Linhares, S., Gewandsznajoer, F. (2000).Biologia hoje. Editora Atica, São Paulo.

[7] Amabis, J. M., Martho, G. R. (2001). Fundamentos de biologia moderna. Editora Moderna, São Paulo.

[8] Lawson, A. E. (1993). The Importance of Analogy: A Prelude to the Special Issue, in Journal of Research in Science Teaching 30, 10, 1213-1214.

[9] Oliva, J. M. (2003). Rutinas y Guiones del profesorado de ciencias ante el usa de analogias como recurso de aula:

http://www.saum.uvigo.es/reec/volumenes/volumen2/Numero1/Art2.pdf. (Consultada em 2009)

[10] Rigas, P., Valanides, N. (2004). Teaching Biology with written analogies. University of Cyprus: http://www1.phys.uu.nl/esera2003/programme/pdf/099S.pdf (Consultada em 2009)

[11] Justiniano, S.C. B., Moroni, R. B., Moroni F. T. e Santos, J. M. M. (2006). Genética revisando e fixando conceitos. Genética na Escola, 51-52.

[12] Moreira, L. M. (2007). O uso do corpo como ferramenta pedagógica:

um modelo alternativo que desconsidera a ausência de recursos específicos para o ensino de bioquímica e biologia molecular no ensino fundamental. Revista Brasileira de Ensino de bioquímica e biologia molecular. 1-14 : http://www.sbbq.org.br/revista (acesso 2008).

Edição semestral, publicada pela Sociedade Brasileira de Bioquímica e Biologia Molecular (SBBq), disponibilizada a todos os interessados no site http://www.sbbq.org.br/revista, com artigos e materiais didáticos, softwares e outros assuntos. Editores: Bayardo B. Torres, Eduardo Galembeck - Fone: (19) 3521-6138 Fax: (19) 3521-6129 